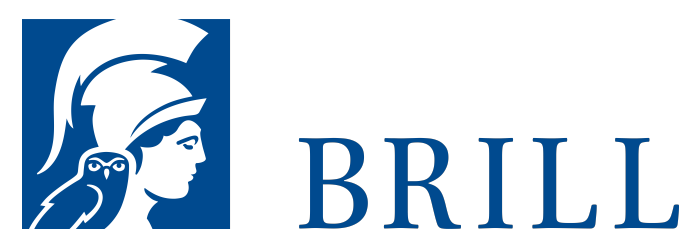

\title{
Selections from the Third Groningen Round Table
}

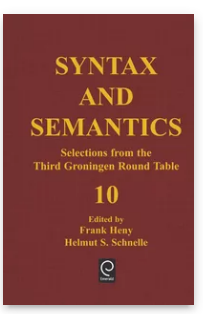

Pages: xii, 382 pp.

Language:

English

Subjects:

Morphology \& Syntax,

Languages and Linguistics, Semantics,

Languages and Linguistics, Pragmatics \& Discourse Analysis, Languages and Linguistics

Publisher: Brill

Series:

Syntax and Semantics,

Volume: 10

E-Book (PDF)

Released online:

13 Jan 2020

ISBN: 978-90O4-373o8-2 List price USD \$222.00

Hardback

Publication date: 28 Aug 1979 
For more information see brill.com

ISBN: $978-$ O1- $^{-}$

26-13510-7

List price

USD.D $\$ 209.00$

Order information: Order online at brill.com

+44 330333 0049 | customerservices@brill.com

Submission information: brill.com/authors

Titles published by Brill | Fink, Brill | mentis or Brill | Schöningh:

+49(o)71 5413279216 | brill@brocom.de 